\title{
Roosters affected by epididymal lithiasis present local alteration in vitamin D3, testosterone and estradiol levels as well as estrogen receptor $2(\beta)$ expression
}

\author{
André G Oliveira, Rubem A P Dornas, Lílian C Praes, Rex A Hess ${ }^{1}$, Germán A B Mahecha \\ and Cleida A Oliveira
}

Department of Morphology, Universidade Federal de Minas Gerais (UFMG), Avenida Antônio Carlos 6627, Caixa Postal 486, CEP 31.270-901 Belo Horizonte, Minas Gerais, Brazil and ${ }^{1}$ Department of Comparative Biosciences, University of Illinois, 2001 S. Lincoln, Urbana, Illinois 61802, USA

Correspondence should be addressed to C A Oliveira; Email: cleida@icb.ufmg.br

\begin{abstract}
Epididymal lithiasis is a reproductive dysfunction of roosters that is associated with loss of fertility and is characterized by the formation of calcium stones in the lumen of the efferent ductules of the epididymal region. The efferent ductules of birds are responsible for the reabsorption of the fluid coming from the testis as well as luminal calcium. It has been hypothesized that the epididymal stone formation may be related to the impairment of local fluid or calcium homeostasis, which depends on hormones such as estradiol ( $\left.E_{2}\right)$. Therefore, this study aimed to investigate possible alterations in the expression of ER $\alpha$ (ESR1) and ER $\beta$ (ESR2) in the epididymal region of roosters affected by epididymal lithiasis. The study was performed by immunohistochemistry and western blotting assays. In addition, the concentrations of $E_{2}$, vitamin D3, and testosterone, which are also key hormones in maintenance of calcium homeostasis, were determined in the plasma and epididymal region, by ELISA. It was observed that ESR2 expression is increased in all segments of the epididymal region of affected roosters, whereas ESR1 levels are not altered. Moreover, the hormone concentration profiles were changed, as in the epididymal region of roosters with lithiasis the $E_{2}$ levels were increased and vitamin D3 as well as testosterone concentrations were significantly decreased. These results suggest that a hormonal imbalance may be involved with the origin and progression of the epididymal lithiasis, possibly by affecting the local fluid or calcium homeostasis.

Reproduction (2011) 142 439-446
\end{abstract}

\section{Introduction}

Epididymal lithiasis is a reproductive dysfunction characterized by the formation of luminal stones rich in calcium in the rooster's epididymal region Janssen et al. 2000, Mahecha et al. 2002, Oliveira \& Oliveira 2011). Animals affected by this anomaly present severe testicular and epididymal alterations. Testicular damage includes dilation of seminiferous tubules, sloughing of the seminiferous epithelium, and increase in Leydig cell frequency in the interstitial tissue (Janssen et al. 2000, Mahecha et al. 2002, Oliveira et al. 2008). The testicular alterations result in reduced fertility in affected animals (Janssen et al. 2000). Interestingly, the reduction in fertility was observed after natural and even artificial insemination with equivalent numbers of sperm obtained from the semen of affected animals (Janssen et al. 2000). This result suggested that adverse effects of epididymal lithiasis on fertility could be attributed to alterations in the production of sperm at the testicular level, but also possibly as a consequence of impaired maturation as they traverse the epididymal region. In birds, the epididymal region is composed of the rete testis, proximal and distal efferent ductules and epididymal duct (Aire 1979a, Aire \& Soley 2000, Oliveira et al. 2007), which are also affected by the presence of the stones (Janssen et al. 2000, Mahecha et al. 2002, Oliveira et al. 2008).

The efferent ductules are the most affected segment of the rooster's genital tract in animals with epididymal lithiasis (Janssen et al. 2000, Mahecha et al. 2002). Besides the fact that the formation of the calcium stones is restricted to the efferent ductules, epithelial injury as well as the occurrence of frequent mononuclear cell infiltrates adjacent to affected ductules are common features in affected animals (Janssen et al. 2000, Mahecha et al. 2002, Boltz et al. 2004, 2006, Jackson et al. 2006, Oliveira et al. 2008). In birds, the efferent ductules compose up to $60 \%$ of the epididymal region (Aire 1979b, Oliveira et al. 2007). It has been shown that these ductules are responsible for testicular fluid and calcium reabsorption, an essential function involved in 
sperm concentration and maturation (Clulow \& Jones 1988, 2004).

It is well known that the fluid reabsorptive function of the mammalian efferent ductules are under the influence of estrogen and its receptors ESR1 and ESR2, that are highly expressed within the epithelial cells of these ductules (Goyal et al. 1997, Hess et al. 1997, Nielsen et al. 2001, Zhou et al. 2001, Nie et al. 2002, Oliveira et al. 2002, 2005, Picciarelli-Lima et al. 2006, Joseph et al. 2011). In addition to the regulation of fluid transport, estrogens also participate in the maintenance of calcium homeostasis in several tissues, including in birds, by regulating the expression and activity of proteins involved in the calcium homeostasis (Hoenderop et al. 2005, de Matos 2008). In roosters, the relevance of estrogen action in the epididymal region has not been determined. Previous studies have shown that $\mathrm{P} 450$ aromatase, the enzyme responsible for estrogen production (Kwon et al. 1995), as well as estrogen receptor (ER), are present in the rooster epididymal region (Kwon et al. 1997). However, a differential expression of ESR1 and ESR2 has recently been described for this species (Oliveira et al. 2011). It was shown that ESR2 is widely expressed within the epididymal region, whereas ESR1 was mostly found in the distal efferent ductules, suggesting that, as in mammals, these ductules may be important targets for estrogen action in roosters (Oliveira et al. 2011).

It has been hypothesized that the epididymal stone formation may be related to impairment of fluid or calcium transepithelial transport in the efferent ductules (Oliveira et al. 2008, Oliveira \& Oliveira 2011). Therefore, based on the dual role of estrogens and their receptors in the transepithelial transport of fluid and calcium, this study aimed to investigate the expression of ESR1 and ESR2 in the epididymal region of roosters affected by epididymal lithiasis as well as the concentrations of estrogens in the plasma and epididymal region. In addition, we also addressed the levels of vitamin D3 and testosterone, considering that previous studies have shown alterations in both vitamin D3 receptor (VDR) and androgen receptor in the epididymal region of roosters affected by lithiasis (Oliveira et al. 2008).

\section{Results \\ Epididymal region}

The epididymal region of roosters lies closely attached to the testis and is formed by the extratesticular rete testis, proximal, and distal efferent ductules as well as connecting and epididymal ducts (Fig. 1). In males affected by the epididymal lithiasis, stones were visible macro- and microscopically within the lumen of efferent ductules, especially in the proximal efferent ductules that also presented loss of epithelial folding (Fig. 1).

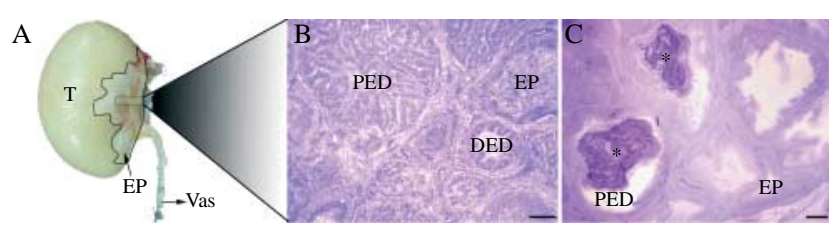

Figure 1 The epididymal region of roosters. (A) Macroscopical view of the testis and epididymal region (highlighted area). (B) The epididymal region of non-affected animals showing proximal efferent ductules with highly folded epithelium (PED), distal efferent ductules (DED), and epididymal duct (EP). (C) Epididymal region of roosters affected by epididymal lithiasis showing luminal stones $\left({ }^{*}\right)$ and loss of epithelial folding in proximal efferent ductules (PED). Epididymal duct (EP) shows no evident alterations. Bar in $B$ and $C=100 \mu \mathrm{m}$. T, testis; $E P$, epididymal region; Vas, deferent duct.

The efferent ductules compose the majority of the volume $(23 \%)$ of the ducts in the epididymal region of the roosters, followed by the rete testis $(16 \%)$ and connecting ducts/epididymal duct (10\%). A great proportion of the region is formed by connective tissue $(51 \%)$. No alterations in the proportion of the epididymal region components were found between animals nonaffected and affected males.

\section{ESR1 and ESR2 detection}

Western blotting assays for ESR1 and ESR2 detected specific positive protein bands of 67 and $54 \mathrm{kDa}$ respectively (Fig. 2). These results are in agreement with previous published data for these receptors in birds (Gonzalez-Moran et al. 2008, Oliveira et al. 2011). A significant increase $(26 \%)$ in ESR2 expression was observed in the epididymal region of roosters affected by epididymal lithiasis compared with non-affected animals (Fig. 2B). On the other hand, ESR1 expression was not statistically significant between the groups (Fig. 2A).

The highest ESR1 labeling was found in the nuclei of non-ciliated cells of the distal efferent ductules, followed by principal and basal cells in the epididymal duct (Fig. 3A-C). On the other hand, the non-ciliated cells of the proximal efferent ductules were intermittently positive for ESR1. Cells of the connective tissue and ciliated cells of the efferent ductules were not immunolabeled for this protein. Compared with non-affected animals, roosters affected by epididymal lithiasis did not show evident alterations in ESR1 (Fig. 3D-F).

ESR2 was widely expressed in the epididymal region of roosters, as all epithelial cell nuclei as well as connective tissue cells were positive for this protein (Fig. 4A-C). In the efferent ductules, ESR2 immunoreaction was observed in both non-ciliated and ciliated cells lining the epithelium, as well as in principal and basal cells of the epididymal duct. There were no significant differences in ESR2 immunostaining between the segments of the epididymal region in non-affected animals. Compared with non-affected roosters, animals affected by lithiasis presented increased ESR2 labeling in 


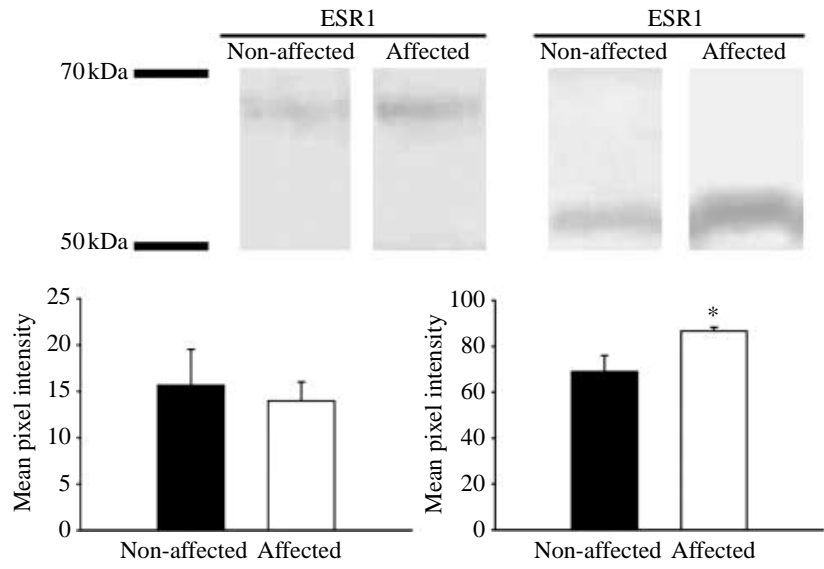

Figure 2 Western blotting analysis of ESR1 and ESR2 in the epididymal region of roosters affected and non-affected by epididymal lithiasis (A). Graphical representation of the image analysis of the ESR1 (B) and ESR2 (C) western blots. $n=5 ;{ }^{*} P \leq 0.05$.

the epithelium of all segments analyzed. On the other hand, the immunoreaction for this receptor in the connective tissue cells was similar in both groups (Fig. 4D-F). In the proximal efferent ductules, ESR2 levels were higher in the non-ciliated cells $(38 \%)$ and in ciliated cells (44\%); whereas in the distal efferent ductules the increase in staining was in the magnitude of 44 and $45 \%$ respectively (Fig. $4 \mathrm{G}$ and $\mathrm{H}$ ). In addition, principal cells lining the epididymal duct showed an increase of $41 \%$ in the immunostaining for this receptor when affected and non-affected animals were compared (Fig. 4l). It is important to highlight that ESR2 was not detected in the mononuclear cells present in the infiltrates adjacent to affected efferent ductules.

\section{Hormone levels}

Estradiol $\left(E_{2}\right)$ levels were increased $95 \%$ in the epididymal region of roosters affected by epididymal lithiasis compared with those not affected, whereas plasma levels were decreased $30 \%$ in these animals (Fig. 5A and B). Conversely, vitamin D3 concentrations presented a decrease of $86 \%$ in the epididymal region and a remarkable increase of about 11 -fold in plasma of affected animals (Fig. 5C and D). Regarding testosterone levels, it was observed a drastic reduction in the concentration of this hormone within the epididymal region and plasma of roosters affected by epididymal lithiasis compared with non-affected animals (84 and $60 \%$, respectively; Fig. 5E and F).

\section{Discussion}

This study demonstrated that roosters affected by epididymal lithiasis had altered expression patterns of estrogen receptors ESR1 and ESR2 compared with control roosters. Paralleling these changes, $E_{2}$ levels were increased in the epididymal region, suggesting that alterations in the estrogen signaling may be associated with epididymal lithiasis. In addition, vitamin D3 and testosterone levels were decreased in the epididymal region of affected roosters. These results add to the limited data about epididymal lithiasis, pointing out that a local hormonal imbalance may be involved with the origin and progression of this anomaly, possibly by affecting the transepithelial calcium transport and/or fluid reabsorption in the efferent ductules.

Roosters affected by the epididymal lithiasis presented decreased $E_{2}$ and testosterone, but increased vitamin D3 plasma levels. It is difficult to determine the consequence of such alterations in calcium stone formation, but, corroborating our findings, altered hormonal profiles have been also associated with the development of calcium stones in the kidney of rodent and human (Iguchi et al. 1999, Yoshioka et al. 2010). In most cases, high levels of circulating estrogen prevents calcium crystal growth and aggregation (Iguchi et al. 1999, Yoshioka et al. 2010), whereas increased circulating vitamin D3 parallel a higher incidence of kidney stones (Worcester \& Coe 2008, Shakhssalim et al. 2011). Because the circulating levels of hormones may not reflect exactly the physiology and function of specific organs, tissue concentrations of $E_{2}$, vitamin D3, and testosterone, were also investigated.

A remarkable characteristic of the avian efferent ductules is their participation in the reabsorption of a

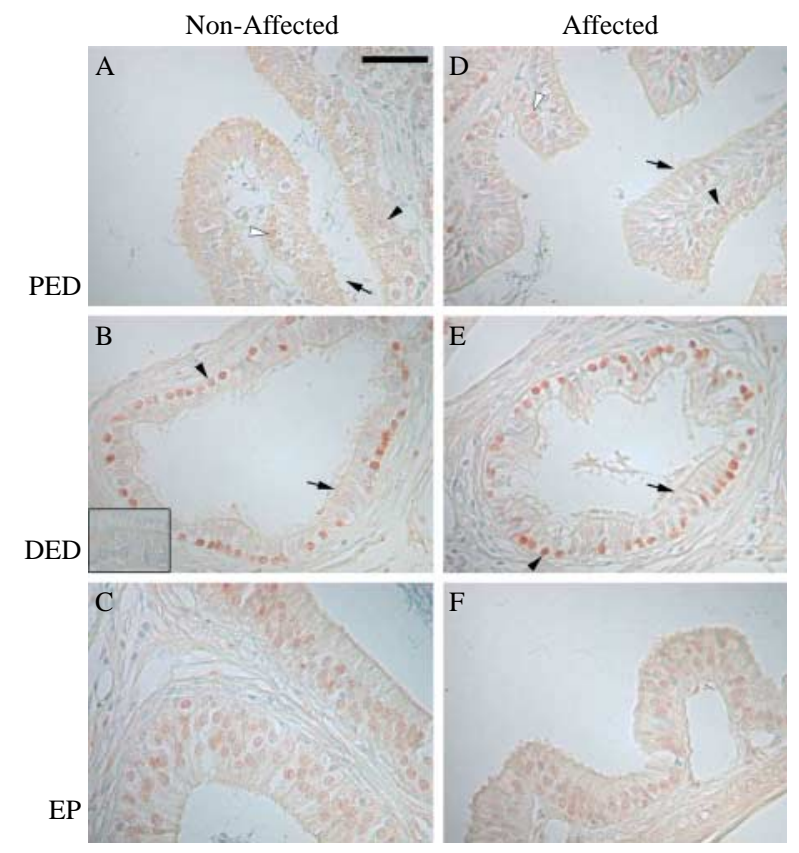

Figure 3 Immunodetection of ESR1 in the epididymal region of roosters not affected (A-C) and affected (D-F) by epididymal lithiasis. PED, proximal efferent ductule; DED, distal efferent ductule; EP, epididymal duct; white arrowheads, ESR1 positive non-ciliated cells; black arrowheads, ESR1 negative non-ciliated cells; arrows, ciliated cells; bar in A, $30 \mu \mathrm{m}$; inset in B, negative control. 


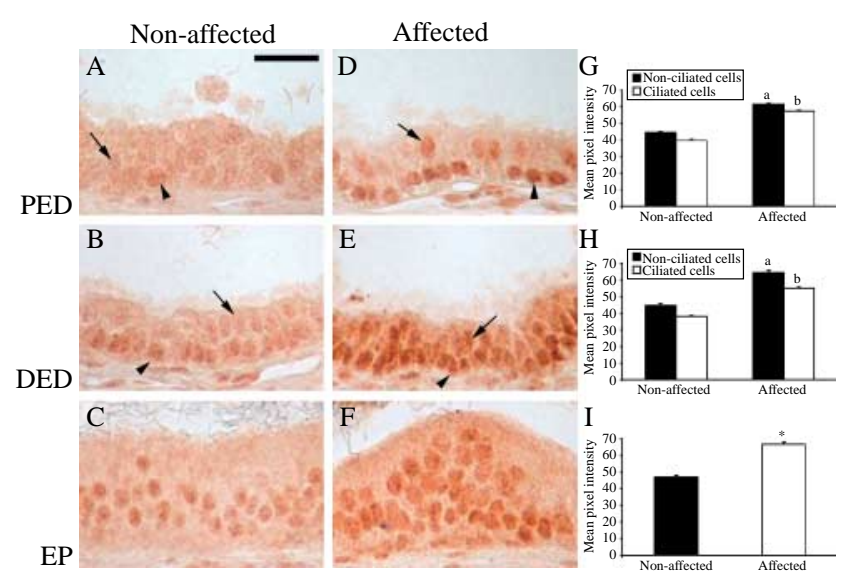

Figure 4 Immunodetection of ESR2 in the epididymal region of roosters non-affected (A-C) and affected (D-F) by epididymal lithiasis. (G-I) Graphical representation of the immunohistochemistry image analysis. PED, proximal efferent ductule; DED, distal efferent ductule; EP, epididymal duct; arrowheads: non-ciliated cells; arrows, ciliated cells. $n=4 ; a=P \leq 0.05$ between non-ciliated cells and $b=P \leq 0.05$ between ciliated cells; ${ }^{*} P \leq 0.05$.

great amount of calcium, besides fluid reabsorption (Clulow \& Jones 2004). Vitamin D3 is recognized as a key hormone in tissue calcium homeostasis (Cai et al. 1993, Hoenderop et al. 2001, 2005, Dick et al. 2003, Meyer et al. 2007). VDR is expressed within the mammalian male genital system (Stumpf et al. 1987, Schleicher et al. 1989, Johnson et al. 1996, Blomberg Jensen et al. 2010), playing an important role in sperm maturation (Blomberg Jensen et al. 2010). In birds, the efferent ductules exhibit greater amount of this receptor among the components of the epididymal region (Dornas et al. 2007). Because VDR was increased in the efferent ductules of roosters affected by epididymal lithiasis (Oliveira et al. 2008), the reduction in local vitamin D3 levels presently found suggests that the VDR upregulation was possibly a compensatory mechanism to reestablish local vitamin D3 action.

$\mathrm{E}_{2}$ level was higher within the epididymal region of roosters with epididymal lithiasis than in non-affected animals. It is known that the biological function of $E_{2}$ is mediated by estrogen receptors ESR1 and ESR2 (Carreau \& Hess 2010), which shares structural similarities but also present functional differences (Kuiper et al. 1996, Heldring et al. 2007). Coincident with the $\mathrm{E}_{2}$ levels, ESR2 was also overexpressed in all segments within the epididymal region, whereas ESR1 levels were not affected. Involvement of ESR2 in other pathological conditions with soft-tissue calcification has been already demonstrated in other species, whereas ESR1 is commonly associated with a protective effect against calcification (Hodgin et al. 2001, Christian et al. 2006). It is known that estrogens are involved in regulation of the male tract luminal osmolarity and acidification (Joseph et al. 2010a, 2010b). Interestingly, acidification of luminal fluid inhibits calcium transcellular reabsorption in the kidney of mammals (Bindels et al. 1994, Hoenderop et al. 2005, Topala et al. 2007). Therefore, it is possible that the impairment in estrogen responsive system within the epididymal region of roosters affected by epididymal lithiasis may also result in alterations in the luminal fluid $\mathrm{pH}$ with consequent negative effects in the local calcium homeostasis.

Vitamin D3, $E_{2}$, and testosterone play important roles in the maintenance of local calcium homeostasis as these hormones modulate the expression of key proteins involved in the transepithelial calcium transport. High levels of vitamin D3 and $E_{2}$ are associated with increased calcium reabsorption, as they promote the expression of the transient receptor potential vanilloid channels (TRPV5), calbindin-D28k (CaBP-D28K), and plasma membrane calcium ATPase (PMCA), including in birds (Cai et al. 1993, Hoenderop et al. 2001, 2005, Van Abel et al. 2002, Dick et al. 2003, Kip \& Strehler 2004, Oz et al. 2007). These proteins participate on the entry of calcium within the cell, its diffusion throughout the cell cytoplasm to the basolateral membranes and calcium extrusion to the extracellular environment respectively (Hoenderop et al. 2005). Moreover, low levels of testosterone increase the expression of the TRPV 5 and CaBP-D28k (Hsu et al. 2010). Furthermore, besides the transcellular pathway, vitamin D3, $\mathrm{E}_{2}$, and testosterone may also influence the paracellular calcium transport (Wada-Hiraike et al. 2006, Fujita et al. 2008, Kong et al. 2008, Braniste et al. 2009, Park et al. 2011). Therefore, even though $\mathrm{E}_{2}$ and testosterone are not considered as calciotropic factors, they may also affect the epithelial calcium transport both through the transcellular and paracellular pathways. Based on this information, and considering that the luminal stones consist primarily by calcium (Janssen et al. 2000, Mahecha et al. 2002), we hypothesize that the imbalance in vitaminD3, estrogen, and androgen responsive systems may result in calcium transport alterations through the transcellular and/or paracellular pathways (Fig. 6). Future detailed studies on the expression of key proteins involved in epithelial calcium transport should better clarify the mechanism of calcium handling in the epididymal region of roosters.

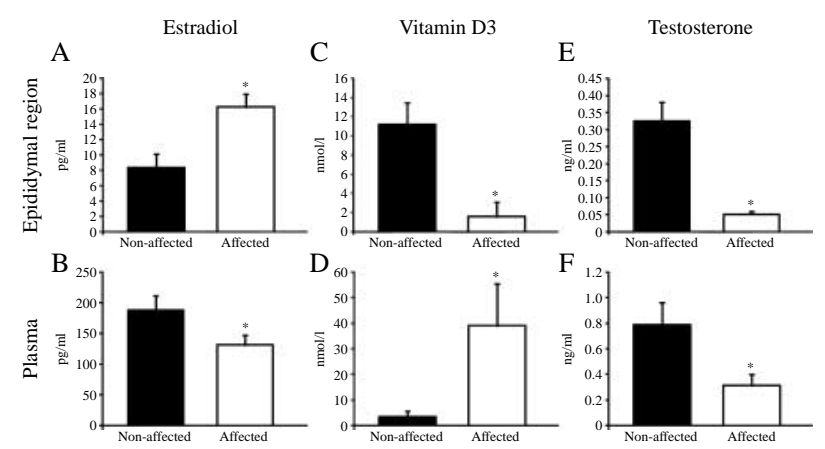

Figure 5 Hormone levels of $(A$ and $B) E_{2}$, $(C$ and $D)$ vitamin $D 3$, and $(\mathrm{E}$ and $\mathrm{F}$ ) testosterone in the epididymal region and plasma of roosters non-affected and affected by epididymal lithiasis. $n=5 ; * P \leq 0.05$. 

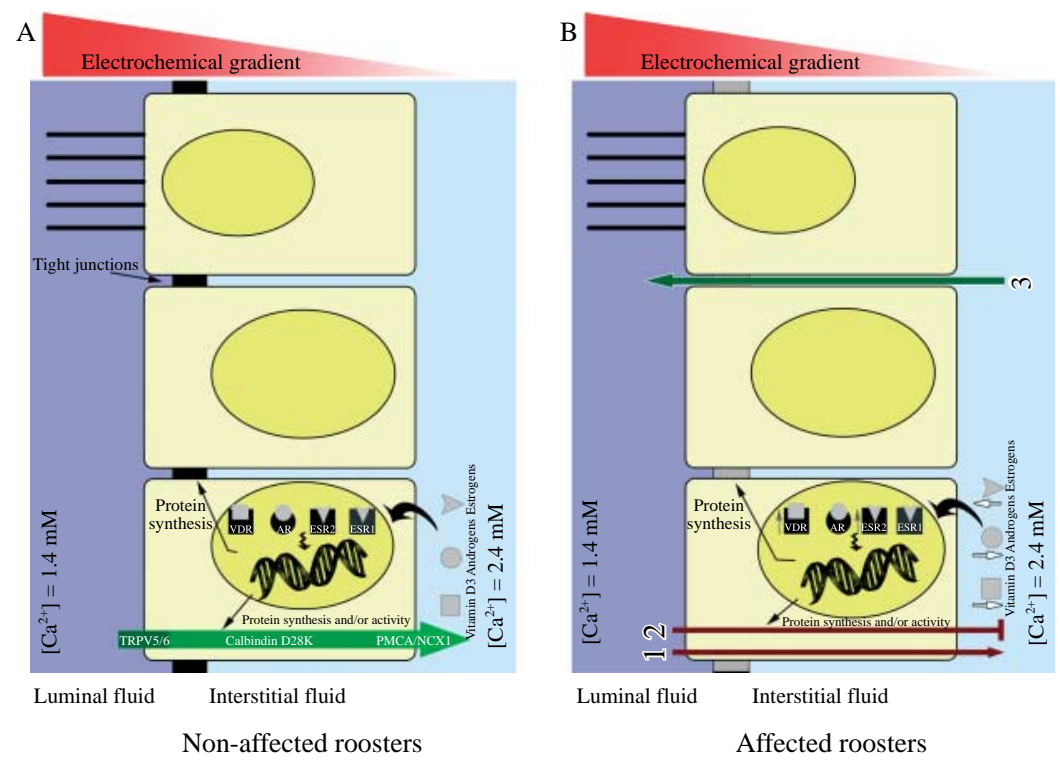

Figure 6 Proposed mechanism for luminal calcium stone formation in the efferent ductules of roosters. (A) In roosters non-affected by epididymal lithiasis, calcium is reabsorbed against an electrochemical gradient (Clulow \& Jones 2004) possibly by the transcellular pathway. This process is mediated by different key proteins (TRPV5 or TRPV6, calbindin-D28K as well as PMCA and NCX1) and regulated by vitamin D3, estrogens, androgens, and their receptors VDR, ESR1/ESR2, and AR (Hoenderop et al. 2005, Hsu et al. 2010). (B) In affected roosters, it is possible that the imbalance of VDR (Oliveira et al. 2008) and ESR2 levels as well as the local concentrations of vitamin D3, $E_{2}$, and testosterone culminate in reduced (1) or impairment (2) in the transepithelial calcium transport. Also, the hormonal imbalance could interfere with paracellular calcium transport, resulting in the transport of this ion toward the lumen (3). As a consequence of events 1-3, individually or synergistically, calcium concentration within the lumen of efferent ductules would be increased creating a favorable microenvironment for calcium aggregation.

In conclusion, vitamin D3, $\mathrm{E}_{2}$, and testosterone levels as well as ESR2, but not ESR1, expression were altered in the epididymal region of roosters affected by epididymal lithiasis. These findings point out that alteration in these hormone responsive systems may result in disruption of local calcium homeostasis, which would culminate in the formation of a favorable microenvironment for the aggregation and development of the luminal calcium stones.

\section{Materials and Methods}

\section{Animals and tissue preparation}

The investigation was performed on the epididymal region of 18 adult cross breed roosters (Gallus domesticus) $\sim 1-2$ years old obtained from commercial sources and housed at the Universidade Federal de Minas Gerais facilities. The animals were kept under natural conditions of light, humidity, and temperature and were allowed free access to water and food (Socil III Guyomarc, Belo Horizonte, Brazil). The principles of research involving animals followed those advocated by the local Ethics Committee published by the CETEA/UFMG (http:// www.ufmg.br/bioetica/coep).

After weighting, the roosters were anesthetized (i.p. lethal dose of sodium pentobarbital $50 \mathrm{mg} / \mathrm{kg}$ body weight) and blood samples were collected by cardiac puncture. The plasma was separated by centrifugation and stored at $-20^{\circ} \mathrm{C}$ for subsequent hormone measurements. Animals were then perfused intracardially with saline and $10 \%$ neutral buffered formalin (NBF) for immunohistochemical studies. After fixation, the epididymal regions were dissected out from the testis. Alternatively, animals were perfused with saline solution only and after dissection; tissues were frozen in liquid nitrogen for western blotting and ELISA analysis.

\section{Diagnostics of epididymal lithiasis}

The macroscopic diagnostic of epididymal lithiasis was performed by the tissue clearing methodology as previously described and validated (Mahecha et al. 2002, Oliveira et al. 2008). Briefly, tissues were rinsed in PBS, transferred to $0.5 \%$ $(\mathrm{w} / \mathrm{v})$ potassium hydroxide and immersed in glycerin solutions $(1: 2,1: 1$, and pure glycerin). The animals were classified as affected or non-affected according to the presence or absence of epididymal stones in the epididymal region. Macroscopical findings were validated by histological evaluations of fixed epididymal fragments that were stained with hematoxylin and eosin (H\&E).

\section{Histology and morphometry}

NBF fixed tissues were processed routinely for paraffin embedding and sectioned at $5 \mu \mathrm{m}$. Then, sections were stained with H\&E and used for histological studies and morphometrical analysis by classical methodology (Weibel 1969, Oliveira et al. 2007). The volumetric density ( $\mathrm{V} v \%)$ of the rete testis, proximal and distal efferent ductules, connecting ducts and epididymal duct as well as the connective tissue in the epididymal region was analyzed using a grid of 400 points. All the points of the grid incident in the ducts of the region were 
scored and the result for each duct was divided by the sum of all points scored to obtain the $\mathrm{V} \vee \%$ of the parameters analyzed. Because differentiation between the connecting and epididymal ducts is difficult (Aire \& Soley 2000, Oliveira et al. 2007), they were considered together.

\section{Western blotting}

For the western blotting assays, epididymal regions of nonaffected and affected roosters ( $n=5$ per group) frozen in liquid nitrogen were used. Following total protein extraction, samples were subjected to continuous electrophoresis using $10 \%$ SDS-PAGE. The separated proteins were transferred to nitrocellulose membranes and blocked with $10 \%$ normal goat serum for $1 \mathrm{~h}$ at room temperature. After incubation for $1 \mathrm{~h}$ with rabbit anti-ESR1 (Clone 60C - Millipore, Temecula, CA, USA) or mouse anti-ESR2 (NCL-ER $\beta$ - Novocastra Laboratories, New Castle, UK) antibodies, used at 1:300 and 1:150 dilution, respectively, the blots were washed in PBS Tween $0.05 \%$ and then incubated in a biotinylated secondary antibody (Dako, Glostrup, Denmark) goat anti-rabbit (for ESR1) or goat antimouse (for ESR2) at 1:1000. The membranes were then incubated with the avidin-biotin complex (Vectastain Elite ABC Kit - Vector Laboratories, Burlingame, CA, USA) for $30 \mathrm{~min}$ and the immunolabeling was visualized with a solution of $0.1 \%(\mathrm{w} / \mathrm{v}) 3,3^{\prime}$-diaminobenzidine in PBS containing 0.05 chloronaphthol $(\mathrm{w} / \mathrm{v}), 16.6$ methanol $(\mathrm{v} / \mathrm{v})$, and $0.04 \%(\mathrm{v} / \mathrm{v})$ $\mathrm{H}_{2} \mathrm{O}_{2}$. The quantification of ESR1 and ESR2 positive bands were estimated as described previously (Oliveira et al. 2008).

\section{Immunohistochemistry}

NBF fixed, paraffin embedded fragments of the epididymal region of non-affected and affected animals ( $n=4$ per group) were used for immunohistochemical studies. To allow comparison between animals, the sections were run in parallel, and the staining was performed in two different sets to confirm the results. Sections were deparaffinized, rehydrated, blocked for endogenous peroxidase and submitted to antigen retrieval by a standard microwave method. The avidin-biotin non-specific binding was blocked using the Vector blocking kit (Vector Laboratories). Sections were then incubated in $10 \%$ normal goat serum to block non-specific binding and then with the primary rabbit anti-ESR1 (Clone 60C - Millipore) or mouse anti-ESR2 (NCL-ER $\beta$ Novocastra Laboratories) antibodies at the dilution of 1:50 and 1:25 respectively. The use of these antibodies has already being validated for rooster tissues (Oliveira et al. 2011). After several washes in PBS, the sections were exposed to a biotinylated goat anti-rabbit (for ESR1) or goat anti-mouse (for ESR2) secondary antibody (Dako) used at 1:50 dilution. The negative controls were obtained by the omission of the primary antibodies followed by the incubation with goat anti-rabbit IgG and goat anti-mouse IgG diluted 1:50 for ESR1 and ESR2 respectively. The sections were then incubated in the avidin-biotin complex (Vectastain Elite ABC Kit - Vector Laboratories). Finally, the immunoreaction was developed in $0.05 \% 3,3^{\prime}$-diaminobenzidine containing $0.01 \%$ ( v/v) $\mathrm{H}_{2} \mathrm{O}_{2}$ in $0.05 \mathrm{M}$ Tris- $\mathrm{HCl}$ buffer, $\mathrm{pH} 7.6$ and stopped in distilled water. Sections were counterstained with Mayer's hematoxylin, dehydrated in ethanol, cleared in xylene, and mounted.

\section{Semi-quantitative immunohistochemical studies}

The intensity of ESR1 and ESR2 immunostaining was estimated by computer-assisted analysis, based on previously reported protocols (Oliveira et al. 2008). Digital images from five different areas of the proximal and distal efferent ductules as well as the epididymal duct of each animal were taken by a Nikon Eclipse E600 microscope (Nikon Co., Melville, NY, USA). The images were processed with Adobe Photoshop (Adobe Systems), converted to the grayscale mode and inverted. The images were then exported to Image-Tool Software (version 3.00, University of Texas Health Sciences Center, USA), for quantitative analysis. For this purpose, 25 nuclei of each cell type positive for the proteins investigated in the efferent ductules and epididymal duct were traced, measured and the pixel intensity was determined for the traced areas. Background intensity was determined by tracing an unlabeled area adjacent to the measured cells. Final pixel intensity was calculated by subtracting the values detected in labeled nuclei from the background.

\section{Hormone measurements}

Vitamin D3, $E_{2}$, and testosterone levels were dosed in the epididymal region and plasma by ELISA assays (Akhlaghi \& Zamiri 2007, Ruwaan et al. 2010). For tissue analysis, epididymal region of affected and non-affected animals $(n=5)$ were frozen in liquid nitrogen and macerated in dry ice. Then, $100 \mathrm{mg}$ tissue were suspended in $250 \mu \mathrm{l}$ of PBS $(\mathrm{pH}$ 7.4), homogenized and sonicated for $1 \mathrm{~min}$. To optimize the results for $\mathrm{E}_{2}$ and testosterone, lipid extraction enrichment with diethyl ether was performed according to a previous study (Hany et al. 1999). The enrichment of vitamin D3 in samples was performed by following manufacturer's instructions. The plasma used in the experiments was obtained after centrifugation of total blood (1800 $\mathrm{g}$ for $10 \mathrm{~min}$ ) in heparin-coated tubes. ELISA measurements were performed according to the protocols provided by the manufacturers of the kits $\left(E_{2}\right.$ and vitamin D3 - DRG Instruments $\mathrm{GmbH}$, Marburg, Germany and testosterone Interkit - Bio Check, Foster City, CA, USA). It was used the same volume of samples per well of the ELISA plates. All samples were measured in duplicate within each assay and all the experiments were repeated in two independent assays. The intra- and inter-assay coefficients of variation (CVs) were 10 and $12 \%$ for vitamin D3, 4.6 and $7.8 \%$ for $E_{2}$, and 7.4 and $5.2 \%$ for testosterone respectively. The sensitivity of the assays was $5.6 \mathrm{nmol} / \mathrm{l}, 9.7 \mathrm{pg} / \mathrm{ml}$, and $0.083 \mathrm{ng} / \mathrm{ml}$ for vitamin D3, $\mathrm{E}_{2}$, and testosterone ELISA Kits respectively.

\section{Statistical analysis}

Differences in hormone concentrations and ESR1 and ESR2 expression in the epididymal region of roosters non-affected and affected by epididymal lithiasis were statistically analyzed by the Student's $t$-test. The analysis of the morphometrical data ( $\mathrm{V} \%$ ) was performed by using ANOVA and Newman-Keuls as post hoc for pairwise comparisons. Differences were considered significant at $P \leq 0.05$. 


\section{Declaration of interest}

The authors declare that there is no conflict of interest that could be perceived as prejudicing the impartiality of the research reported.

\section{Funding}

This work was supported by the Fundação de Amparo à Pesquisa do Estado de Minas Gerais - FAPEMIG/Brazil (grant numbers APQ-4712-3.13/07 and CBB-723/6 to C A Oliveira; scholarships to R A P Dornas and L C Praes) and the Conselho Nacional de Desenvolvimento Cientifico e Tecnológico $\mathrm{CNPq} /$ Brazil (research fellowship to C A Oliveira, doctoral fellowship to A G Oliveira, and technician fellowship).

\section{Acknowledgements}

Authors thank the technical assistance of Pollyana Rabelo Nunes Campos and Elisângela Martins dos Santos.

\section{References}

Aire TA 1979a The epididymal region of the Japanese quail (Coturnix coturnix japonica). Acta Anatomica 103 305-312. (doi:10.1159/ 000145028)

Aire TA $1979 b$ Micro-stereological study of the avian epididymal region. Journal of Anatomy 129 703-706.

Aire TA \& Soley JT 2000 The surface features of the epithelial lining of the ducts of the epididymis of the ostrich (Struthio camelus). Anatomia, Histologia, Embryologia 29 119-126. (doi:10.1046/j.1439-0264.2000. 00247.x)

Akhlaghi A \& Zamiri MJ 2007 Effect of transient prepubertal hypothyrodism on serum testosterone level and seminal characteristics of chickens. Iranian Journal of Veterinary Research 8 23-31.

Bindels RJ, Hartog A, Abrahamse SL \& Van Os CH 1994 Effects of pH on apical calcium entry and active calcium transport in rabbit cortical collecting system. American Journal of Physiology 266 F620-F627.

Blomberg Jensen $M$, Nielsen JE, Jorgensen A, Rajpert-DeMeyts $E$, Kristensen DM, Jorgensen N, Skakkebaek NE, Juul A \& Leffers H 2010 Vitamin D receptor and vitamin D metabolizing enzymes are expressed in the human male reproductive tract. Human Reproduction 25 1303-1311. (doi:10.1093/humrep/deq024)

Boltz DA, Nakai M \& Bahra JM 2004 Avian infectious bronchitis virus: a possible cause of reduced fertility in the rooster. Avian Diseases 48 909-915. (doi:10.1637/7192-040808R1)

Boltz DA, Zimmerman CR, Nakai M, Bunick D, Scherba G \& Bahr JM 2006 Epididymal stone formation and decreased sperm production in roosters vaccinated with a killed strain of avian infectious bronchitis virus. Avian Diseases 50 594-598. (doi:10.1637/7654-052506R.1)

Braniste V, Leveque $M$, Buisson-Brenac C, Bueno $L$, Fioramonti J \& Houdeau E 2009 Oestradiol decreases colonic permeability through oestrogen receptor beta-mediated up-regulation of occludin and junctional adhesion molecule-A in epithelial cells. Journal of Physiology 587 3317-3328. (doi:10.1113/jphysiol.2009.169300)

Cai Q, Chandler JS, Wasserman RH, Kumar R \& Penniston JT 1993 Vitamin $\mathrm{D}$ and adaptation to dietary calcium and phosphate deficiencies increase intestinal plasma membrane calcium pump gene expression. PNAS 90 1345-1349. (doi:10.1073/pnas.90.4.1345)

Carreau S \& Hess RA 2010 Oestrogens and spermatogenesis. Philosophical Transactions of the Royal Society of London. Series B 365 1517-1535. (doi:10.1098/rstb.2009.0235)

Christian RC, Liu PY, Harrington S, Ruan M, Miller VM \& Fitzpatrick LA 2006 Intimal estrogen receptor (ER)beta, but not ERalpha expression, is correlated with coronary calcification and atherosclerosis in pre- and postmenopausal women. Journal of Clinical Endocrinology and Metabolism 91 2713-2720. (doi:10.1210/jc.2005-2672)

Clulow J \& Jones RC 1988 Studies of fluid and spermatozoal transport in the extratesticular genital ducts of the Japanese quail. Journal of Anatomy $1571-11$.

Clulow J \& Jones RC 2004 Composition of luminal fluid secreted by the seminiferous tubules and after reabsorption by the extratesticular ducts of the Japanese quail, Coturnix coturnix japonica. Biology of Reproduction 71 1508-1516. (doi:10.1095/biolreprod.104.031401)

Dick IM, Liu J, Glendenning P \& Prince RL 2003 Estrogen and androgen regulation of plasma membrane calcium pump activity in immortalized distal tubule kidney cells. Molecular and Cellular Endocrinology 212 11-18. (doi:10.1016/j.mce.2003.09.028)

Dornas RA, Oliveira AG, Kalapothakis E, Hess RA, Mahecha GA \& Oliveira CA 2007 Distribution of vitamin D3 receptor in the epididymal region of roosters (Gallus domesticus) is cell and segment specific. General and Comparative Endocrinology 150 414-418. (doi:10.1016/j. ygcen.2006.10.010)

Fujita H, Sugimoto K, Inatomi S, Maeda T, Osanai M, Uchiyama Y, Yamamoto Y, Wada T, Kojima T, Yokozaki H et al. 2008 Tight junction proteins claudin-2 and -12 are critical for vitamin D-dependent $\mathrm{Ca}^{2+}$ absorption between enterocytes. Molecular Biology of the Cell 19 1912-1921. (doi:10.1091/mbc.E07-09-0973)

Gonzalez-Moran MG, Guerra-Araiza C, Campos MG \& Camacho-Arroyo I 2008 Histological and sex steroid hormone receptor changes in testes of immature, mature, and aged chickens. Domestic Animal Endocrinology 35 371-379. (doi:10.1016/j.domaniend.2008.08.001)

Goyal HO, Bartol FF, Wiley AA, Khalil MK, Chiu J \& Vig MM 1997 Immunolocalization of androgen receptor and estrogen receptor in the developing testis and excurrent ducts of goats. Anatomical Record 249 54-62. (doi:10.1002/(SICI)1097-0185(199709)249:1 <54::AID-AR7> 3.0.CO;2-F)

Hany J, Lilienthal H, Sarasin A, Roth-Harer A, Fastabend A, Dunemann L, Lichtensteiger W \& Winneke G 1999 Developmental exposure of rats to a reconstituted PCB mixture or aroclor 1254: effects on organ weights, aromatase activity, sex hormone levels, and sweet preference behavior. Toxicology and Applied Pharmacology 158 231-243. (doi:10.1006/taap. 1999.8710)

Heldring N, Pike A, Andersson S, Matthews J, Cheng G, Hartman J, Tujague M, Strom A, Treuter E, Warner M et al. 2007 Estrogen receptors: how do they signal and what are their targets. Physiological Reviews $\mathbf{8 7}$ 905-931. (doi:10.1152/physrev.00026.2006)

Hess RA, Bunick D, Lee KH, Bahr J, Taylor JA, Korach KS \& Lubahn DB 1997 A role for oestrogens in the male reproductive system. Nature $\mathbf{3 9 0}$ 509-512. (doi:10.1038/37352)

Hodgin JB, Krege JH, Reddick RL, Korach KS, Smithies O \& Maeda N 2001 Estrogen receptor alpha is a major mediator of 17 beta-estradiol's atheroprotective effects on lesion size in $A_{p o e^{-/-}}$mice. Journal of Clinical Investigation 107 333-340. (doi:10.1172/JCI11320)

Hoenderop JG, Muller D, Van Der Kemp AW, Hartog A, Suzuki M, Ishibashi K, Imai M, Sweep F, Willems PH, Van Os CH et al. 2001 Calcitriol controls the epithelial calcium channel in kidney. Journal of the American Society of Nephrology 12 1342-1349.

Hoenderop JG, Nilius B \& Bindels RJ 2005 Calcium absorption across epithelia. Physiological Reviews 85 373-422. (doi:10.1152/physrev. 00003.2004)

Hsu YJ, Dimke H, Schoeber JP, Hsu SC, Lin SH, Chu P, Hoenderop JG \& Bindels RJ 2010 Testosterone increases urinary calcium excretion and inhibits expression of renal calcium transport proteins. Kidney International 77 601-608. (doi:10.1038/ki.2009.522)

Iguchi M, Takamura C, Umekawa T, Kurita T \& Kohri K 1999 Inhibitory effects of female sex hormones on urinary stone formation in rats. Kidney International 56 479-485. (doi:10.1046/j.1523-1755.1999.00586.x)

Jackson UH, Boltz DA, Nakai M, Scherba G, Bunick D \& Bahr J 2006 Prepubertal exposure to the live attenuated avian infectious bronchitis virus induces epididymal stones in the rooster after puberty. Journal of Anatomy 91 116-129.

Janssen SJ, Kirby JD, Hess RA, Rhoads M, Bunick D, Bailey KL, Parsons CM, Wang H \& Bahr JM 2000 Identification of epididymal stones in diverse rooster populations. Poultry Science 79 568-574. 
Johnson JA, Grande JP, Roche PC \& Kumar R 1996 Immunohistochemical detection and distribution of the 1,25-dihydroxyvitamin D3 receptor in rat reproductive tissues. Histochemistry and Cell Biology 105 7-15. (doi:10.1007/BF01450873)

Joseph A, Hess RA, Schaeffer DJ, Ko C, Hudgin-Spivey S, Chambon P \& Shur BD 2010a Absence of estrogen receptor alpha leads to physiological alterations in the mouse epididymis and consequent defects in sperm function. Biology of Reproduction 82 948-957. (doi:10. 1095/biolreprod.109.079889)

Joseph A, Shur BD, Ko C, Chambon P \& Hess RA 2010 b Epididymal hypoosmolality induces abnormal sperm morphology and function in the estrogen receptor alpha knockout mouse. Biology of Reproduction 82 958-967. (doi:10.1095/biolreprod.109.080366)

Joseph A, Shur BD \& Hess RA 2011 Estrogen, efferent ductules, and the epididymis. Biology of Reproduction 84 207-217. (doi:10.1095/ biolreprod.110.087353)

Kip SN \& Strehler EE 2004 Vitamin D3 upregulates plasma membrane $\mathrm{Ca}^{2+}$-ATPase expression and potentiates apico-basal $\mathrm{Ca}^{2+}$ flux in MDCK cells. American Journal of Physiology. Renal Physiology 286 F363-F369. (doi:10.1152/ajprenal.00076.2003)

Kong J, Zhang Z, Musch MW, Ning G, Sun J, Hart J, Bissonnette M \& Li YC 2008 Novel role of the vitamin D receptor in maintaining the integrity of the intestinal mucosal barrier. American Journal of Physiology. Gastrointestinal and Liver Physiology 294 G208-G216. (doi:10.1152/ ajpgi.00398.2007)

Kuiper GG, Enmark E, Pelto-Huikko M, Nilsson S \& Gustafsson JA 1996 Cloning of a novel receptor expressed in rat prostate and ovary. PNAS 93 5925-5930. (doi:10.1073/pnas.93.12.5925)

Kwon S, Hess RA, Bunick D, Nitta H, Janulis L, Osawa Y \& Bahr JM 1995 Rooster testicular germ cells and epididymal sperm contain P450 aromatase. Biology of Reproduction 53 1259-1264. (doi:10.1095/ biolreprod53.6.1259)

Kwon S, Hess RA, Bunick D, Kirby JD \& Bahr JM 1997 Estrogen receptors are present in the epididymis of the rooster. Journal of Andrology $\mathbf{1 8}$ 378-384.

Mahecha GA, Oliveira CA, Balzuweit K \& Hess RA 2002 Epididymal lithiasis in roosters and efferent ductule and testicular damage. Reproduction 124 821-834. (doi:10.1530/rep.0.1240821)

de Matos R 2008 Calcium metabolism in birds. Veterinary Clinics of North America. Exotic Animal Practice 11 59-82. (doi:10.1016/j.cvex.2007. 09.005)

Meyer MB, Zella LA, Nerenz RD \& Pike JW 2007 Characterizing early events associated with the activation of target genes by 1,25dihydroxyvitamin D3 in mouse kidney and intestine in vivo. Journal of Biological Chemistry $282 \quad$ 22344-22352. (doi:10.1074/jbc. M703475200)

Nie R, Zhou Q, Jassim E, Saunders PT \& Hess RA 2002 Differential expression of estrogen receptors alpha and beta in the reproductive tracts of adult male dogs and cats. Biology of Reproduction 66 1161-1168. (doi:10.1095/biolreprod66.4.1161)

Nielsen M, Bogh IB, Schmidt M \& Greve T 2001 Immunohistochemical localization of estrogen receptor-alpha in sex ducts and gonads of newborn piglets. Histochemistry and Cell Biology 115 521-526. (doi:10. 1007/s004180100269)

Oliveira AG \& Oliveira CA 2011 Epididymal lithiasis in roosters: in the middle of the way there was a stone. Life Sciences [in press]. (doi:10. 1016/j.Ifs.2011.04.021)

Oliveira CA, Zhou Q, Carnes K, Nie R, Kuehl DE, Jackson GL, Franca LR, Nakai M \& Hess RA 2002 ER function in the adult male rat: short- and long-term effects of the antiestrogen ICI 182780 on the testis and efferent ductules, without changes in testosterone. Endocrinology 143 2399-2409. (doi:10.1210/en.143.6.2399)

Oliveira CA, Carnes K, Franca LR, Hermo L \& Hess RA 2005 Aquaporin-1 and -9 are differentially regulated by oestrogen in the efferent ductule epithelium and initial segment of the epididymis. Biology of the Cell 97 385-395. (doi:10.1042/BC20040078)

Oliveira AG, Telles LF, Hess RA, Mahecha GA \& Oliveira CA 2007 Effects of the herbicide roundup on the epididymal region of drakes Anas platyrhynchos. Reproductive Toxicology 23 182-191. (doi:10.1016/j. reprotox.2006.11.004)

Oliveira AG, Dornas RA, Kalapothakis E, Hess RA, Mahecha GA \& Oliveira CA 2008 Vitamin D3 and androgen receptors in testis and epididymal region of roosters (Gallus domesticus) as affected by epididymal lithiasis. Animal Reproduction Science 109 343-355. (doi:10.1016/j.anireprosci.2007.11.009)

Oliveira AG, Dornas RA, Mahecha GA \& Oliveira CA 2011 Occurence and cellular distribution of estrogen receptors ERalpha and ERbeta in the testis and epididymal region of roosters. General and Comparative Endocrinology 170 597-603. (doi:10.1016/j.ygcen.2010.11.016)

Oz OK, Hajibeigi A, Howard K, Cummins CL, van Abel M, Bindels RJ, Word RA, Kuro-o M, Pak CY \& Zerwekh JE 2007 Aromatase deficiency causes altered expression of molecules critical for calcium reabsorption in the kidneys of female mice. Journal of Bone and Mineral Research 22 1893-1902. (doi:10.1359/jbmr.070808)

Park CJ, Lee JE, Oh YS, Shim S, Nah WH, Choi KJ \& Gye MC 2011 Expression of claudin-1 and -11 in immature and mature pheasant (Phasianus colchicus) testes. Theriogenology 75 445-458. (doi:10.1016/ j.theriogenology.2010.09.012)

Picciarelli-Lima P, Oliveira AG, Reis AM, Kalapothakis E, Mahecha GA, Hess RA \& Oliveira CA 2006 Effects of 3-beta-diol, an androgen metabolite with intrinsic estrogen-like effects, in modulating the aquaporin-9 expression in the rat efferent ductules. Reproductive Biology and Endocrinology 4 51. (doi:10.1186/1477-7827-4-51)

Ruwaan JS, Rekwot PI, Abdu PA, Omontese BO, Obidi JA \& Chiezei NP 2010 Effect of a velogenic Newcastle disease virus on tetosterone concentration and gonadal sperm reserves of vaccinated Shikabrown cocks. Research Journal of Poultry Sciences 3 48-53. (doi:10.3923/ rjpscience.2010.48.53)

Schleicher G, Privette TH \& Stumpf WE 1989 Distribution of soltriol $(1,25(\mathrm{OH}) 2$-vitamin D3) binding sites in male sex organs of the mouse: an autoradiographic study. Journal of Histochemistry and Cytochemistry 37 1083-1086. (doi:10.1177/37.7.2543697)

Shakhssalim N, Roohi Gilani K, Parvin M, Mohammadi Torbati P, Kashi AH, Azadvari M, Golestan B \& Basiri A 2011 An assessment of parathyroid hormone, calcitonin, 1,25 (OH)(2) vitamin D3, estradiol and testosterone in men with active calcium stone disease and evaluation of its biochemical risk factors. Urological Research 39 1-7. (doi:10.1007/ s00240-010-0276-3)

Stumpf WE, Sar M, Chen K, Morin J \& DeLuca HF 1987 Sertoli cells in the testis and epithelium of the ductuli efferentes are targets for $3 \mathrm{H} \mathrm{1,25}$ $(\mathrm{OH}) 2$ vitamin D3. An autoradiographic study. Cell Tissue Research 247 453-455. (doi:10.1007/BF00218327)

Topala CN, Bindels RJ \& Hoenderop JG 2007 Regulation of the epithelial calcium channel TRPV5 by extracellular factors. Current Opinion in Nephrology and Hypertension 16 319-324. (doi:10.1097/MNH. 0b013e3281c55f02)

Van Abel M, Hoenderop JG, Dardenne O, St Arnaud R, Van Os $\mathbf{C H}$, Van Leeuwen HJ \& Bindels RJ 2002 1,25-Dihydroxyvitamin D(3)independent stimulatory effect of estrogen on the expression of ECaC1 in the kidney. Journal of the American Society of Nephrology 13 2102-2109. (doi:10.1097/01.ASN.0000022423.34922.2A)

Wada-Hiraike O, Imamov O, Hiraike H, Hultenby K, Schwend T, Omoto Y, Warner M \& Gustafsson JA 2006 Role of estrogen receptor beta in colonic epithelium. PNAS 103 2959-2964. (doi:10.1073/pnas.0511271103)

Weibel ER 1969 Stereological principles for morphometry in electron microscopic cytology. International Review of Cytology 26 235-302.

Worcester EM \& Coe FL 2008 New insights into the pathogenesis of idiopathic hypercalciuria. Seminars in Nephrology 28 120-132. (doi:10. 1016/j.semnephrol.2008.01.005)

Yoshioka I, Tsujihata M, Momohara C, Akanae W, Nonomura N \& Okuyama A 2010 Effect of sex hormones on crystal formation in a stoneforming rat model. Urology 75 907-913. (doi:10.1016/j.urology.2009. 09.094)

Zhou Q, Clarke L, Nie R, Carnes K, Lai LW, Lien YH, Verkman A, Lubahn D, Fisher JS, Katzenellenbogen BS et al. 2001 Estrogen action and male fertility: roles of the sodium/hydrogen exchanger-3 and fluid reabsorption in reproductive tract function. PNAS 98 14132-14137. (doi:10.1073/ pnas.241245898)

Received 20 April 2011

First decision 17 May 2011

Accepted 13 June 2011 